\title{
Article \\ Effects of Ce-Rich Misch Metal on the Microstructures and Tensile Properties of as-Cast Mg-7Al-3Sn-1Zn Alloys
}

\author{
Guo-Jun Liu ${ }^{1, *(D)}$, Yan-Hua Sun ${ }^{2}$, Nan Xia ${ }^{1}$ and Xiao-Fang Guan ${ }^{1}$ \\ 1 School of Materials Science and Engineering, Nanling Campus, Jilin University, No. 5988 Renmin Street, \\ Changchun 130025, China; 1031xianan@sina.com (N.X.); xfguan@jlu.edu.cn (X.-F.G.) \\ 2 Kunming Metallurgical Research Institute Co., Ltd., Kunming 650031, China; syh19771108@163.com \\ * Correspondence: liuguojun@jlu.edu.cn
}

check for updates

Citation: Liu, G.-J.; Sun, Y.-H.;

Xia, N.; Guan, X.-F. Effects of Ce-Rich Misch Metal on the Microstructures and Tensile Properties of as-Cast Mg-7Al-3Sn-1Zn Alloys. Metals 2021, 11, 1648. https://doi.org/10.3390/ met11101648

Academic Editor: Frank Czerwinski

Received: 18 September 2021

Accepted: 11 October 2021

Published: 18 October 2021

Publisher's Note: MDPI stays neutral with regard to jurisdictional claims in published maps and institutional affiliations.

Copyright: (c) 2021 by the authors. Licensee MDPI, Basel, Switzerland. This article is an open access article distributed under the terms and conditions of the Creative Commons Attribution (CC BY) license (https:// creativecommons.org/licenses/by/ $4.0 /)$.
Abstract: The effects of small amounts of Ce-rich misch metal (Mm: 0.5, 1.0 and $2.0 \mathrm{wt} . \%)$ addition on the microstructure and tensile properties of as-cast Mg-7Al-3Sn-1Zn wt.\% (ATZ731) alloy have been investigated. The addition of $\mathrm{Mm}$ restricts the formation of the $\mathrm{Mg}_{17} \mathrm{Al}_{12}$ phase but greatly promotes the $\mathrm{Al}_{4} \mathrm{Mm}$ phase. The proper Mm addition enhances the strength and ductility of ATZ731 alloys at both room temperature (RT) and $175{ }^{\circ} \mathrm{C}$. ATZ731 alloys with $1.0 \mathrm{wt} . \% \mathrm{Mm}$ addition exhibit an advantageous combination strength and ductility, with the ultimate tensile strength (UTS), $0.2 \%$ yield strength (YS) and elongation to failure $\left(\mathrm{E}_{\mathrm{f}}\right)$ at $175{ }^{\circ} \mathrm{C}$ of $\sim 148 \mathrm{MPa}, \sim 102 \mathrm{MPa}$ and $\sim 28 \%$, improved by $\sim 14.7 \%, \sim 24.3 \%$ and $\sim 53.8 \%$, respectively, compared to those of ATZ731 alloy. This enhancement is primarily owing to the refined microstructures and the high thermal stability of $\mathrm{Al}_{4} \mathrm{Mm}$ at the elevated temperature in contrast with that of the $\mathrm{Mg}_{17} \mathrm{Al}_{12}$ phase. The fracture modes are also discussed.

Keywords: magnesium alloys; misch metal; $\mathrm{Al}_{4} \mathrm{Mm}$; tensile properties; $\mathrm{Mg}-\mathrm{Al}-\mathrm{Sn}$

\section{Introduction}

$\mathrm{Mg}$ alloys have attracted increasing attention for automobile, subway, and biomedical applications due to their high specific strength, ease of recycling and degradability [1,2]. $\mathrm{Mg}$-Al serials alloys currently lead the market of commercial casting Mg alloys; however, their wide application as metal structure materials is still limited because of their weak strength at temperatures above $120{ }^{\circ} \mathrm{C}$ due to the softening $\beta-\mathrm{Mg}_{17} \mathrm{Al}_{12}$ phase with a eutectic temperature of $437^{\circ} \mathrm{C}[3,4]$. Therefore, further study on $\mathrm{Mg}$-Al alloy is needed to enlarge its application.

Recently, Mg-Al-Sn (AT) alloys have been showing promise. The addition of Sn to Mg alloy has many advantages [5-11]. Sn causes solid solution strengthening (solubility of $\mathrm{Sn}$ in $\mathrm{Mg}$ is $14.85 \mathrm{wt} . \%$ at the eutectic temperature of $561^{\circ} \mathrm{C}$ ), precipitation strengthening, and creep performance at elevated temperatures in binary $\mathrm{Mg}$-Sn alloys. It also provides a beneficial effect on the elongation via decreasing of stacking fault energy of pure $\mathrm{Mg}$ proved by first principle calculation [8-11]. However, the resultant mechanical properties of Mg-Sn binary alloys cannot satisfy the commercial requirements, stimulating the fast development of AT based Mg alloys [12]. There are many papers on AT alloys with low Al contents, but researches with $\mathrm{Al}$ contents above 6 wt.\% are few [5,8,13-16]. Luo et al. [17] investigated AT alloys with varying additions of Al (5-9 wt.\%) and Sn (1-5 wt.\%) prepared by permanent mould, in which the optimised AT72 alloy had enhanced strength and ductility in contrast with the commercial AZ91 alloy. The volume fraction of $\mathrm{Mg}_{2} \mathrm{Sn}$ and $\mathrm{Mg}_{17} \mathrm{Al}_{12}$ are $0.33 \%$ and $6.46 \%$, respectively. Meanwhile, the coarse eutectic phases along the grain boundaries decrease the ductility of AT alloys with the increasing addition of $\mathrm{Al}$ and Sn. To modify these coarse microstructures, $\mathrm{Zn}$ was introduced into Mg-Al$\mathrm{Sn}$ alloys [18,19]. Moreover, the addition of $\mathrm{Zn}$ refined microstructures (grain size and secondary phase) attributed to the super strength and ductility compared to $\mathrm{Mg}-\mathrm{Al}-\mathrm{Sn}$ 
alloys [18-20]. Wang and Pan confirmed that $0.5-2.0 \mathrm{wt} . \% \mathrm{Zn}$ addition refined the microstructures of AT82 alloys contributing to the enhanced ductility [18,19]. Liu et al. [20] reported that adding $3 \mathrm{wt} . \% \mathrm{Zn}$ decreased the solid solubility of both $\mathrm{Sn}$ and $\mathrm{Al}$ in Mg-9Al$6 \mathrm{Sn}$ alloy and produced fine-scale $\mathrm{Mg}_{2} \mathrm{Sn}$ and $\mathrm{Mg}_{17} \mathrm{Al}_{12}$ particles. Moreover, $\mathrm{Zn}$ addition remarkably refined the $\mathrm{Mg}_{2} \mathrm{Sn}$ phase in as-cast $\mathrm{Mg}$-Sn alloys and changed the orientation relationships between $\mathrm{Mg}_{2} \mathrm{Sn}$ and $\alpha-\mathrm{Mg}$ under peak-aged conditions [21,22]. Based on the development of ATZ alloys and considering the mechanical properties of ATZ alloys at high temperatures, the content of Sn should be appropriately increased, while that of $\mathrm{Al}$ should be somewhat reduced in the designed alloys referring to AT82 alloy. Therefore, Mg-7Al-3Sn-1Zn wt.\% (ATZ731) alloy was designed as the based alloy in this work, which is expected to have the desirable tensile property. However, the inherent properties of $\mathrm{Mg}_{17} \mathrm{Al}_{12}$ with a low melting point limit the strength at an elevated temperature. Hence, it is crucial to reduce the volume fraction of $\mathrm{Mg}_{17} \mathrm{Al}_{12}$, which is simultaneously replaced by the high thermal stability of Al-containing phases in ATZ731 alloy, to enhance their high-temperature strength [23-25].

To achieve this goal for ATZ731 alloys, alloying might be a feasible method to modify the microstructures and properties. Ce-rich misch metal (Mm), as one kind of rare-earth (RE) element, was often used in $\mathrm{Mg}$ and $\mathrm{Al}$ alloys and altered the corrosion resistance, formality, and mechanical properties, as well as the microstructures of these alloys [23-27]. Since $\mathrm{Mm}$ is cheaper than pure RE elements, it is preferred in many industries. Moreover, alloying element $\mathrm{Al}$ will react with the added $\mathrm{Mm}$ to form the high-melting $\mathrm{Al}-\mathrm{Mm}$ phases in $\mathrm{Mg}$ - $\mathrm{Al}$ alloys [25]. Therefore, $\mathrm{Mm}$ may be a suitable candidate for ATZ Mg alloys to qualify the microstructures and mechanical properties. When minor $\mathrm{Mm}$ was introduced into $\mathrm{Mg}-\mathrm{Al}$ alloys, the thermally stable $\mathrm{Al}_{x} \mathrm{Mm}_{y}$ intermetallic compounds were formed with the decreasing fraction of $\mathrm{Mg}_{17} \mathrm{Al}_{12}$, resulting in superior strength at high temperatures [26]. The values of $x$ and $y$ in $\mathrm{Al}_{x} \mathrm{Mm}_{y}$ greatly depend on the fabrication processes and the mass ratio of $\mathrm{Al} / \mathrm{Mm}$. Generally, there are three intermetallic compounds, such as $\mathrm{Al}_{11} \mathrm{Mm}_{3}, \mathrm{Al}_{4} \mathrm{Mm}$, and $\mathrm{Al}_{2} \mathrm{Mm}$, that usually appear in $\mathrm{Mm}$-containing $\mathrm{Mg}-\mathrm{Al}$ alloys [25]. Employed 1.25 wt.\% Mm in AZ91 alloy refined the grain size and produced rod-like $\mathrm{Al}_{4}(\mathrm{Ce}, \mathrm{La})$ compound [28], whereas $0.3-0.6 \mathrm{wt} . \% \mathrm{Mm}$ addition caused a decrease of the mean diameters of both $\alpha-\mathrm{Mg}$ and $\mathrm{Mg}_{17} \mathrm{Al}_{12}$ precipitations in AZ91 alloy [27]. The addition of $0.44 \mathrm{wt} . \% \mathrm{Mm}$ improved the strength and ductility of die-cast AZ91D alloy at $170{ }^{\circ} \mathrm{C}$ and attributed to the high thermal stability Al-Mm phases, which effectively hindered the grain boundaries glide and cracks propagation [29]. Another paper reported that the simultaneous additions of $0.7 \mathrm{wt} . \% \mathrm{Mn}$ and $\mathrm{Mm}$ refined grains and produced the new need-like $\mathrm{Al}_{4} \mathrm{Mm}$ phase in wrought $\mathrm{AZ61}$ alloy, which conduces to the nucleation of dynamic recrystallisation at elevated temperatures [30]. Note that, $0.9 \mathrm{wt} . \%$ (0.4 Y combined with $0.5 \mathrm{Nd}$ ) [23], $1.5 \mathrm{wt} . \% \mathrm{Mm}$ [31] and $0.44 \mathrm{wt} . \% \mathrm{Mm}$ [29] is required to the optimal mechanical properties for AT42, AZ81 and AZ91D alloy, respectively. However, there is a contrary opinion that a small addition of Mm (0.2-1.2 wt.\%) combined with $\mathrm{Mn}$ led to the grain coarsening in AZ31, AZ61 and AZ91 alloy prepared by sand casting [32]. The mentioned papers mainly focused on the microstructures and tensile properties of $\mathrm{Mm}$-adding Mg-Al-Zn alloys, while the studies on the Mm-adding ATZ alloys are very few. The tensile properties of as-cast ATZ alloys at high temperatures still are not reported. Most importantly, the appropriate addition of Mm is very different for alloys with various compositions to gain optimal performance.

Thus, this study investigates the effect of the small addition of cheap Mm on the microstructures and tensile properties of as-cast Mg-7Al-3Sn-1Zn wt.\% alloy. The fracture mode was discussed with fracture morphologies.

\section{Materials and Methods}

Pure $\mathrm{Mg}, \mathrm{Al}, \mathrm{Sn}$, and $\mathrm{Zn}$ (>99.9 wt.\%), and Mg-23.2 wt.\% Ce-rich misch metal (Mm: Ce 65.8, La 26.52, Nd 5.82, and $\operatorname{Pr} 1.78 \mathrm{wt} . \%$ ) master alloy were used to fabricate Mg-7Al$3 \mathrm{Sn}-1 \mathrm{Zn}-x \mathrm{Mm}(x=0,0.5,1.0$, and $2.0 \mathrm{wt} . \%)$ alloys. These alloys were marked as ATZ731, 
ATZE7310, ATZE7311, and ATZE7312 (Table 1), respectively, to narrate conveniently in the following. The alloys were melted by an electric-resistance furnace protected under $\mathrm{CO}_{2}$ and $\mathrm{SF}_{6}$ followed by pouring into a preheated $\left(\sim 200^{\circ} \mathrm{C}\right)$ grey iron mould at $\sim 700{ }^{\circ} \mathrm{C}$.

Table 1. Chemical composition of the experiment alloys.

\begin{tabular}{cccccccccc}
\hline \multirow{2}{*}{ Alloy } & \multicolumn{10}{c}{ Composition (wt.\%) } \\
\cline { 2 - 10 } & Al & Sn & Zn & Ce & La & Nd & Pr & Total (Mm) & Mg \\
\hline ATZ731 & 7.453 & 2.967 & 1.105 & - & - & - & - & - & Bal. \\
ATZE7310 & 7.378 & 3.192 & 1.055 & 0.226 & 0.091 & 0.020 & 0.006 & 0.343 & Bal. \\
ATZE7311 & 7.217 & 3.188 & 1.190 & 0.518 & 0.209 & 0.046 & 0.014 & 0.786 & Bal. \\
ATZE7312 & 7.218 & 3.117 & 1.090 & 1.188 & 0.478 & 0.105 & 0.032 & 1.803 & Bal. \\
\hline
\end{tabular}

The actual components of as-cast alloys were checked by an X-ray fluorescence spectrometer (XRF-1800, Shimadzu Sequential, Kyoto, Japan) with the analysis results listed in Table 1. The phase composition was analysed by X-ray diffraction (XRD; DX-2700B Cu $\mathrm{K}_{\alpha}$ radiation at $40 \mathrm{kV}$ and $30 \mathrm{~mA}$ ) (HaoYuan, Dandong, China). Microstructures were observed by optical microscopy (OM; Carl Zeiss Axio Imager.A2m, Göttingen, Germany) and scanning electron microscopy (SEM; ZEISS VOA-18, Göttingen, Germany) with an energy dispersive spectrometer (EDS) to investigate the distribution of alloying elements. Tensile properties were evaluated by a material testing system (Instron5869, Instron, Norwood, USA) at a strain rate of $1.0 \times 10^{-3} \mathrm{~s}^{-1}$ at RT and $175^{\circ} \mathrm{C}$ for at least three samples. To keep good repeatability, at least three tensile samples were tested, and average mechanical properties were recorded. The samples were heated at $175^{\circ} \mathrm{C}$ for $8 \mathrm{~min}$ prior to testing at this temperature. Phase evolution of $\sim 20 \mathrm{mg}$ samples was recorded by a differential scanning calorimeter (DSC, SDT-Q600, Lindon, UT, USA) with Pt crucible and the reference crucible at heating rates of $10^{\circ} \mathrm{C} / \mathrm{min}$ ranging from 675 to $300{ }^{\circ} \mathrm{C}$ under the protection of high-purity Ar atmosphere. The grain size of the solution-treated samples was measured by Nanomeaure 3.0 software [33]. The average volume fraction of secondary phases in as-cast alloys was calculated via the examination for at least ten SEM images by the software of Axio Vision version 4.8 (ZEISS VOA-18, Göttingen, Germany).

For metallographic observation, the as-cast specimens cut from the same place of the ingots were etched with a mixed solution of nitric acid $(2 \mathrm{~mL})$ and absolute ethanol (48 mL) for 10 15 s after grinding with 600, 1000, and 2000 mesh SiC sandpaper in turn and polishing by $0.5 \mu \mathrm{m}$ diamond abrasion paste followed by cleaning in absolute ethanol. The tensile samples, as dogbone-like, are nominal size of the width $4 \mathrm{~mm}$, gage length $30 \mathrm{~mm}$ and thickness $2.0 \mathrm{~mm}$. The solid solution treatment of samples was heat-treated first at $420^{\circ} \mathrm{C}$ for $20 \mathrm{~h}$, then at $1{ }^{\circ} \mathrm{C} / \mathrm{min}$ increased up to $480^{\circ} \mathrm{C}$ holding for $2 \mathrm{~h}$ followed by water $\left(\sim 70^{\circ} \mathrm{C}\right)$ quenching. The DSC samples cut from the ingots were discs with $\sim 0.5 \mathrm{~mm}$ thickness and $3 \mathrm{~mm}$ diameter.

\section{Results and Discussion}

\subsection{Phases Composition and Microstructures}

Figure 1 shows the XRD patterns of as-cast samples. ATZ731 alloys clearly consist of $\alpha$ $\mathrm{Mg}, \mathrm{Mg}_{17} \mathrm{Al}_{12}$, and $\mathrm{Mg}_{2} \mathrm{Sn}$ phases (Figure 1a) similar to those in Mg-Al-Sn-(Zn) alloys [34]. Small amounts of $\mathrm{Mm}$ addition caused the new diffraction peaks (Figure $1 \mathrm{~b}-\mathrm{e}$ ), which are identified to be $\mathrm{Al}_{4} \mathrm{Mm}$ (most of $\mathrm{Al}_{4} \mathrm{Ce}$ ) [35]. Moreover, the strength of $\mathrm{Al}_{4} \mathrm{Mm}$ intensity increased with $\mathrm{Mm}$ increasing. For the ATZE7312 alloy, the intensity of $\mathrm{Al}_{4} \mathrm{Mm}$ became strong, while that of $\mathrm{Mg}_{17} \mathrm{Al}_{12}$ at $\sim 36^{\circ}$ changed to weak compared with ATZ731 alloy, indicating that the increasing $\mathrm{Mm}$ promotes the formation of $\mathrm{Al}_{4} \mathrm{Mm}$ but suppresses the $\mathrm{Mg}_{17} \mathrm{Al}_{12}$ phase. From the evolution of $\mathrm{Mg}_{2} \mathrm{Sn}$ diffraction peaks, it seems that the Mm addition has a little effect on $\mathrm{Mg}_{2} \mathrm{Sn}$ may be related to the detection limit of XRD. The formation of the $\mathrm{Al}_{4} \mathrm{Mm}$ phase was explained by the different electro-negativity between $\mathrm{Mm}$ and $\mathrm{Mg}$, $\mathrm{Al}, \mathrm{Sn}, \mathrm{Zn}$, which suggests that $\mathrm{Mm}$ easily reacts with $\mathrm{Al}[23,35]$. This new phase is $\mathrm{Al}_{4} \mathrm{Mm}$, but not the $\mathrm{Al}_{11} \mathrm{Mm}_{3}$ phase, which appeared in $\mathrm{Mg}$-Al-Mm alloy where the $\mathrm{Mm} / \mathrm{Al}$ mass 
ratio is above 1.4 as recommended by Pettersen [36]. Su et al. [35] investigated the Al-Ce intermetallic compounds in as-cast $\mathrm{Mg}$-Al-Zn-Ce alloys by thermodynamic calculation and the experiments in which the alloys were prepared by gravity casting. It was found that $\mathrm{Al}_{4} \mathrm{Ce}$ formed because of the low atomic ratio between $\mathrm{Ce}$ and $\mathrm{Al}$ as well as the dominant kinetic conditions, which is more likely to satisfy the nucleation and growth requirements of the $\mathrm{Al}_{4} \mathrm{Ce}$ compound. None of the $\mathrm{Zn}$-containing phase was detected, possibly due to the low content of $\mathrm{Zn}$ in samples and the relative high solid solution of $\mathrm{Zn}$ in $\mathrm{Mg}$ (6.2 wt.\% in eutectic temperature) according to binary $\mathrm{Mg}-\mathrm{Zn}$ phase diagram associated with the other papers $[19,20]$. Besides, the melting temperatures of $\mathrm{Al}_{4} \mathrm{Mm}$ are higher than that of $\mathrm{Mg}_{17} \mathrm{Al}_{12}$ (i.e., $\mathrm{Al}_{4} \mathrm{Ce}$ of $1276{ }^{\circ} \mathrm{C}, \mathrm{Mg}_{17} \mathrm{Al}_{12}$ of $437^{\circ} \mathrm{C}$ ) [35]. Thus, the thermally stable $\mathrm{Al}_{4} \mathrm{Mm}$ phase can strongly affect the tensile properties of alloys at a high temperature.

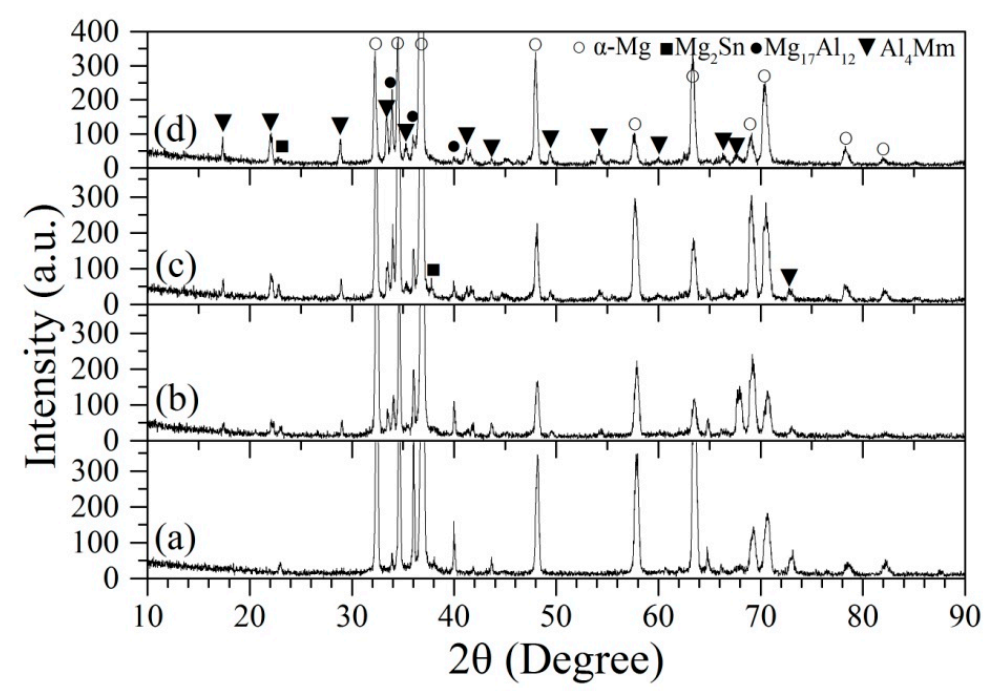

Figure 1. XRD patterns of as-cast samples for (a) ATZ731, (b) ATZE7310, (c) ATZE7311 and (d) ATZE7312 alloys.

Figure 2 presents the typical SEM morphologies of as-cast samples, in which Figure 2a-d are the low magnify of ATZ731, ATZE7310, ATZE7311, and ATZE7312, and Figure 2e-h represents the local high magnify of (Figure 2a-d), respectively. Furthermore, EDS results are shown in Figure 3 and listed in Table 2. For ATZ731 alloy, masses of grey semicontinuous compounds correspond to eutectic $\beta-\mathrm{Mg}_{17} \mathrm{Al}_{12}$ phase distributed along the grain boundaries as pointed by blue arrows, while the white strip-like phases adhered to $\beta$ phases belong to divorced $\mathrm{Mg}_{2} \mathrm{Sn}$ as pointed by green arrows (Figure $2 \mathrm{a}, \mathrm{b}$ ) based on $X R D$ results (Figure 1) and EDS results (Figure 3 ). This indicates that the phase composition of ATZ731 alloy is very similar to those in Mg-7Al-2Sn alloy and Mg-8Al-2Sn-1Zn alloys [18,19]. When $0.5 \mathrm{wt} . \% \mathrm{Mm}$ was added in ATZ731 alloy, the new phase of $\gamma-\mathrm{Al}_{4} \mathrm{Mm}$, small size of $\beta$ and $\mathrm{Mg}_{2} \mathrm{Sn}$, and few lamella secondary precipitates of $\beta\left(\beta^{\prime}\right)$ phase can be observed compared to ATZ731 alloy. The $\gamma$ phase has three different morphologies as rod-, particle- and feather-like, while the volume fraction of the feather-like is very few. Moreover, both the quantity and size of $\beta$ phase were reduced in contrast with the based alloy. With further increase of $\mathrm{Mm}$, the volume fraction and size of $\gamma$ phase were obviously increased (Figure 2c,d), especially for feather-like $\gamma$ phase segregating within grains and at the grain boundaries. While the volume fraction of $\beta$ was reduced, and its morphology was changed from the coarse semi-continuous-like to block- or particle-like, indicating that the $\mathrm{Mm}$ addition promotes the output of $\gamma$ and restricts the formation of $\beta$ phase. The size of $\mathrm{Mg}_{2} \mathrm{Sn}$ clearly was reduced with the $\mathrm{Mm}$ increasing, possibly related to the refined $\beta$ phase. It is interesting that ATZE7311 alloy showed the maximum volume fraction $\beta^{\prime \prime}$ phase pointed by white arrows among these samples. In addition, the EDS analysis of point $\mathrm{A}$ showed that the atomic ratio values of $\mathrm{Al}$ to $\mathrm{Mm}$ is 3.86 very near four. This further proved these phases were $\mathrm{Al}_{4} \mathrm{Mm}$ well agreed with $\mathrm{XRD}$ results [37]. The concentration of 
divorced eutectic $\mathrm{Mg}_{2} \mathrm{Sn}$ phase seems relatively stable because of the non-appearance of Sn-containing ternary phase (Figure 3), unlike that in the Mg-Sn-RE (Ce, Y, Nd) systems, where $\mathrm{MgSnCe} / \mathrm{Y} / \mathrm{Nd}$ formed decreased the fraction of $\mathrm{Mg}_{2} \mathrm{Sn}$ [17,38]. Thus, the increasing addition of $\mathrm{Mm}$ not only promotes the crystallisation and growth of $\mathrm{Al}_{4} \mathrm{Mm}$ but suppresses the $\mathrm{Mg}_{17} \mathrm{Al}_{12}$ phase. In addition, the volume fraction of secondary phases was carefully calculated with the average values are $7.1 \pm 0.2,8.6 \pm 0.26,10.8 \pm 0.32$, and $12.2 \pm 0.37 \%$ for ATZ731, ATZ7310, ATZE7311, and ATZE7312 alloy, respectively. It indicates that the volume fraction of secondary phases increased with Mm increasing.
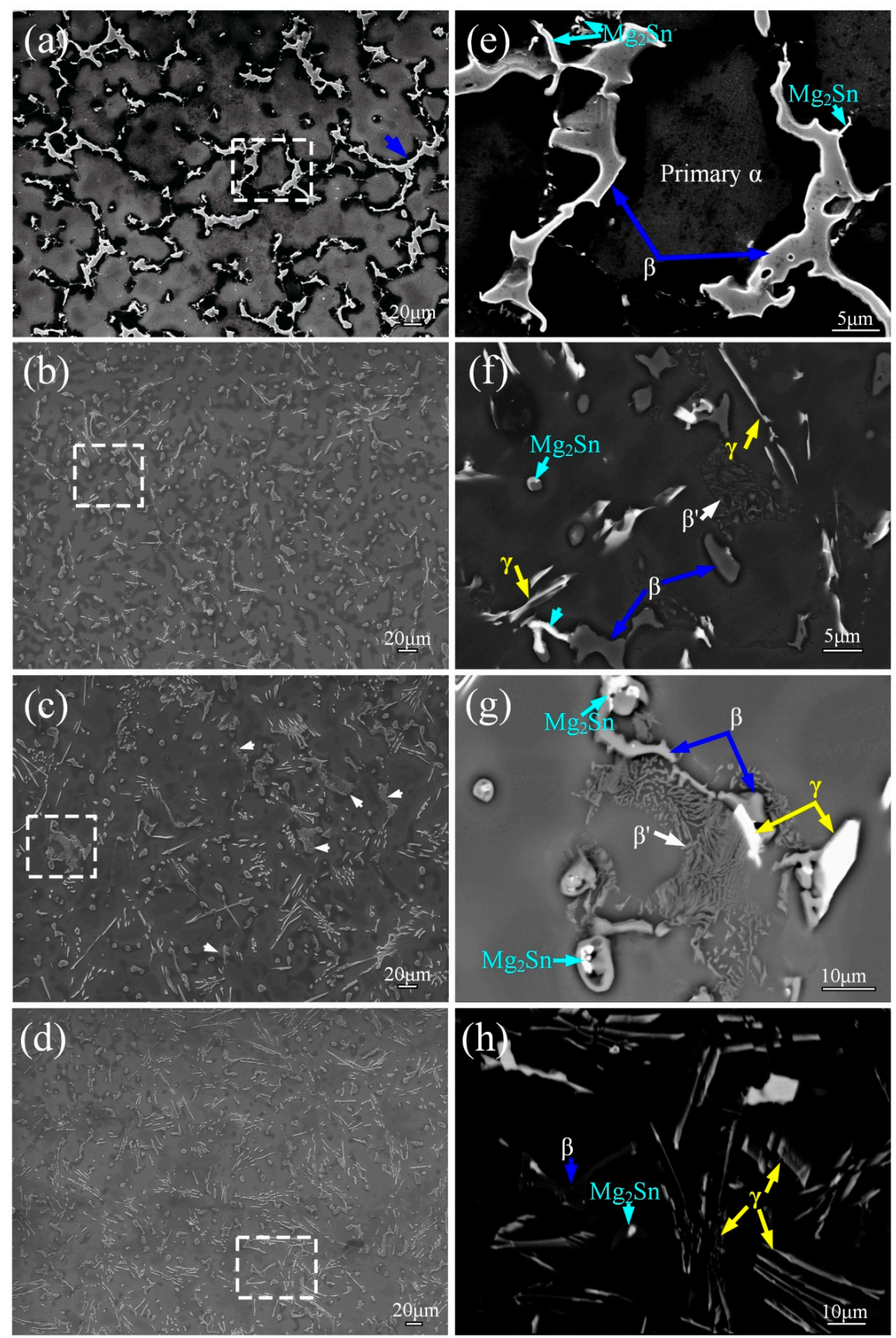

Figure 2. The typical SEM morphologies of as-cast samples for (a,e) ATZ731, (b,f) ATZE7310, (b,c,f,g) ATZE7311 and $(\mathbf{d}, \mathbf{h})$ ATZE7312. Note that $(\mathbf{e}-\mathbf{h})$ are the high magnification BSD of local $(\mathbf{a}-\mathbf{d})$ as pointed by the dotted line square respectively. $\beta$ represents $\mathrm{Mg}_{17} \mathrm{Al}_{12}$ phase, while $\gamma$ is $\mathrm{Al}_{4} \mathrm{Mm}$ phase. 


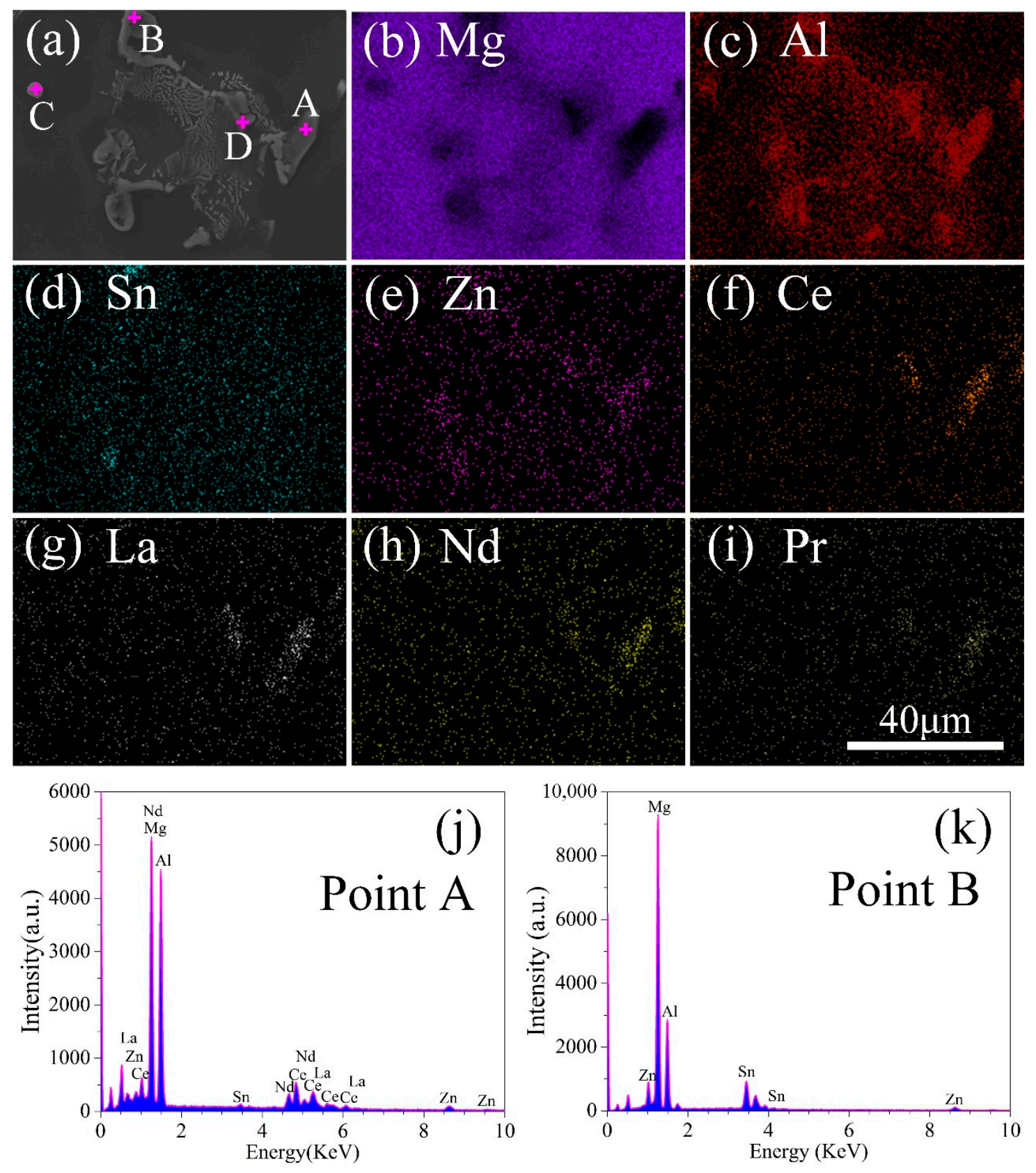

Figure 3. SEM morphology of as-cast ATZE7311 alloy and the EDS results. (a) surface morphology, and (b-i) are the corresponding distribution of $\mathrm{Mg}, \mathrm{Al}, \mathrm{Sn}, \mathrm{Zn}, \mathrm{Ce}, \mathrm{La}, \mathrm{Nd}$ and $\operatorname{Pr}$ on (a), respectively. $(\mathbf{j}, \mathbf{k})$ are the point EDS results of the points of A and B in (a).

Table 2. Elementary compositions of the points showed in Figure 3 and the compositions of the phases.

\begin{tabular}{cccccccccc}
\hline \multirow{2}{*}{ Number. } & \multicolumn{8}{c}{ Composition (at.\%) } & \multirow{2}{*}{ Possible Phases } \\
\cline { 2 - 7 } & $\mathbf{M g}$ & $\mathbf{A l}$ & $\mathbf{S n}$ & $\mathbf{Z n}$ & $\mathbf{C e}$ & $\mathbf{L a}$ & $\mathbf{N d}$ & $\mathbf{P r}$ & \\
\hline $\mathrm{A}$ & 35.35 & 50.64 & 0.86 & 2.80 & 5.44 & 3.6 & 0.37 & 0.94 & $\mathrm{Mg}_{17} \mathrm{Al}_{12}, \mathrm{Al}_{4} \mathrm{Mm}$ \\
B & 62.26 & 11.38 & 23.93 & 2.43 & - & - & - & - & $\mathrm{Mg}_{2} \mathrm{Sn}$ \\
C & 69.34 & 26.44 & 1.35 & 2.87 & - & - & - & - & $\mathrm{Mg}_{17} \mathrm{Al}_{12}$ \\
D & 43.96 & 46.73 & 0.93 & 2.9 & 1.96 & 2.66 & 0.29 & 0.58 & $\mathrm{Al}_{4} \mathrm{Mm}$ \\
\hline
\end{tabular}

To evaluate the grain size of $\alpha-\mathrm{Mg}$ for as-cast alloys, Figure 4 represents the images of the solution-treated samples. The grain size dramatically decreased from $276 \pm 15 \mu \mathrm{m}$ 
of ATZ731 to $190 \pm 11 \mu \mathrm{m}$ of ATZE7310, $124 \pm 5 \mu \mathrm{m}$ of ATZE7311 and $156 \pm 7 \mu \mathrm{m}$ of ATZE7312, indicating that Mm effectively refined the grain size of ATZ731 alloy (Figure 4a-d). However, the grain size of ATZE7312 further increased to $156 \mu \mathrm{m}$ (Figure 4d), revealing that these refinement effects became weak in ATZ731 alloy with the excessive $\mathrm{Mm}$ addition. This phenomenon was often observed in $\mathrm{Mg}$ alloys with excessive RE addition related to RE-containing phases with the high melting temperature and the possible segregation of RE [24,39]. For example, the addition of Y above 0.9 wt.\% in AZ91 alloy caused the large grain size of $\alpha-\mathrm{Mg}$ [27]. Besides, a large number of the undissolved $\mathrm{Al}_{4} \mathrm{Mm}$ phases can be observed on the Mm-containing samples.
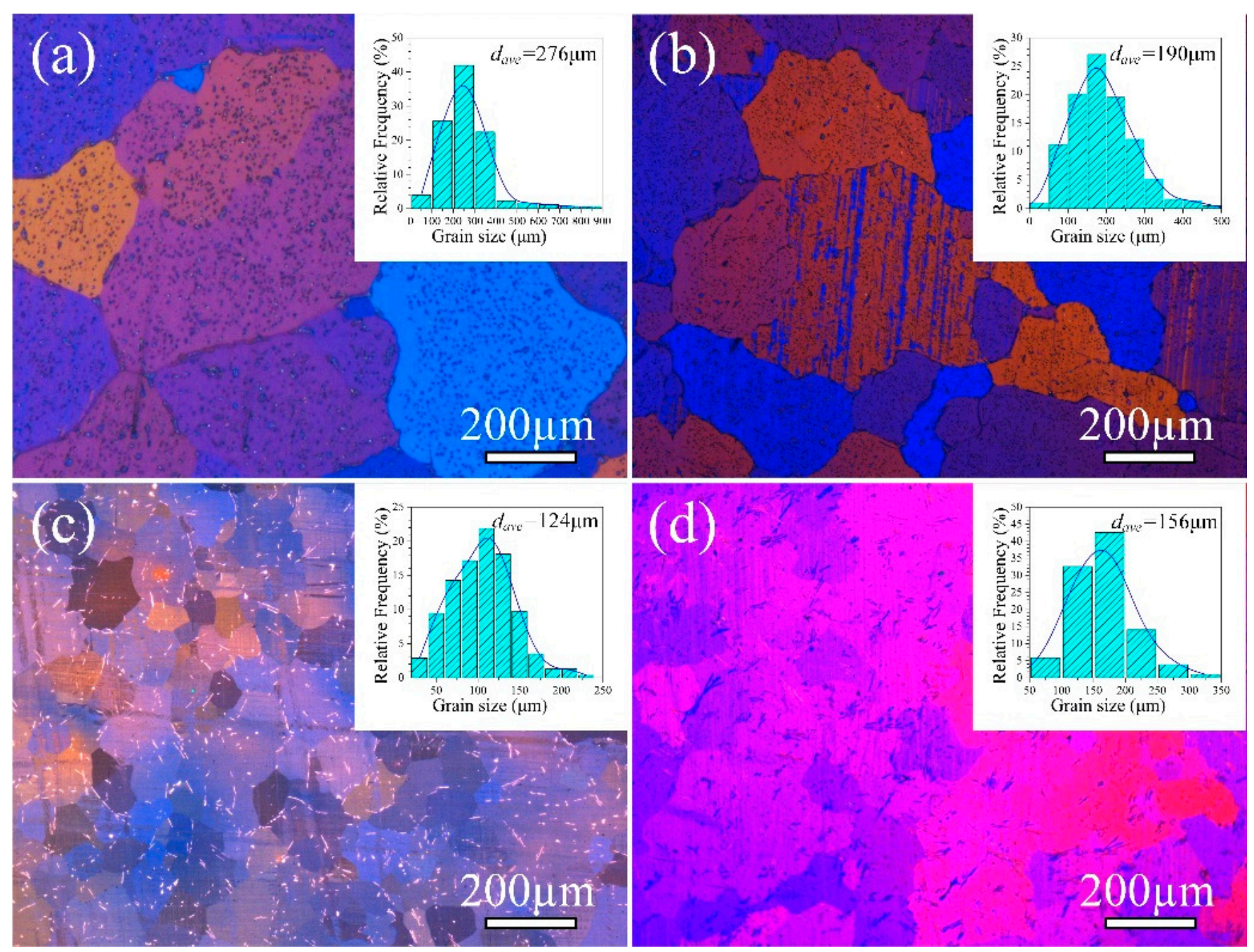

Figure 4. Optical images of solution-treated samples for (a) ATZ731, (b) ATZE7310, (c) ATZE7311 and (d) ATZE7312. The insets are the corresponding statistics results of grain size with $d_{a v e}$ represents the average values of grain size.

The refined microstructures of ATZ731 alloy after minor Mm addition can be explained in the following. According to the solidification theory of metals, the grain size of $\alpha-\mathrm{Mg}$ is mainly dependent on the degree of heterogeneous nucleation and the level of undercooling during the solidification process [40]. $\gamma-\mathrm{Al}_{4} \mathrm{Mm}$ phase was formed prior to $\alpha-\mathrm{Mg}, \mathrm{Mg}_{2} \mathrm{Sn}$, and $\mathrm{Mg}_{17} \mathrm{Al}_{12}$ in $\mathrm{Mg}-\mathrm{Al}-\mathrm{Sn}-\mathrm{Zn}-\mathrm{Mm}$ alloys because of its high eutectic temperature during solidification. Xiao [24] suggested that the preferentially formed $\mathrm{Al}_{4} \mathrm{Mm}$ particles cannot act as the nucleation sites of $\alpha-\mathrm{Mg}$, meaning that the heterogeneous nucleation is a determinant of the refined $\alpha-\mathrm{Mg}$ in Mm-added alloys [24]. Consequently, the preferential partition behaviour of ATZ731 alloys caused by the added Mm during solidification has to be considered $[29,34]$. Since the dissolved atoms of alloying elements were pushed forward at 
the $\alpha-\mathrm{Mg}$ growth front leading to a great constitutional supercooling near the growth front during solidification, which contributed to the refined $\alpha-\mathrm{Mg}$ (Figure 4). In the case of the $\beta-\mathrm{Mg}_{17} \mathrm{Al}_{12}$ phase in Mm-containing alloys (Figures 2 and 3 ), its volume fraction, as well as its size, was reduced owing to the formation of $\mathrm{Al}_{4} \mathrm{Mm}$ particles as previously mentioned. As for the divorced eutectic $\mathrm{Mg}_{2} \mathrm{Sn}$ particle, it nucleated and grew to coexist with the refined $\beta$ phases, and then the $\mathrm{Mg}_{2} \mathrm{Sn}$ phase was also refined, as observed in Figures 2 and 3. With respect to the $\gamma$ phase, its volume fraction and size rose upon the addition of $\mathrm{Mm}$. The increased volume fraction of $\gamma$ phase lowered not only the concentration of $\mathrm{Mm}$ in front of the solid/liquid interface but also the constitutional supercooling degree in the growth front of the alloy melt, causing the weak refinement effect on the microstructure as observed in Figures 2-4. Additionally, supposing that $2.0 \mathrm{wt} . \% \mathrm{Mm}$ completely reacted with $\mathrm{Al}$ in the alloys, $\mathrm{Al}$ still was excessive compared to $\mathrm{Mm}$ by calculating the atom ratio between $\mathrm{Al}$ and $\mathrm{Mm}$, indicating that $\beta$ phase should be formed during solidification even considering the relatively high solubility of $\mathrm{Al}$ in $\mathrm{Mg}$ at the eutectic temperature of binary Mg-Al alloys.

To investigate the effect of Mm contents on the solidification behaviour of ATZ731, Figure 5 shows the typical DSC curves of ATZE7310 and ATZE7311 alloys compared to that of ATZ731 alloy. All the curves exhibited two exothermic peaks, which corresponded to the transformations of $\alpha-\mathrm{Mg}$ and $\beta$ phase, respectively. The addition of $\mathrm{Mm}$ greatly decreased the initial temperatures of $\beta$ phase transformation but raised the end temperature of $\alpha-\mathrm{Mg}$ transformation from $587^{\circ} \mathrm{C}$ of ATZ731 to $594{ }^{\circ} \mathrm{C}$ of ATZE7311. This suggests that the solidification rate of ATZE7310 and ATZE7311 alloys were faster than the based alloy, contributing to the refined $\alpha-\mathrm{Mg}$.

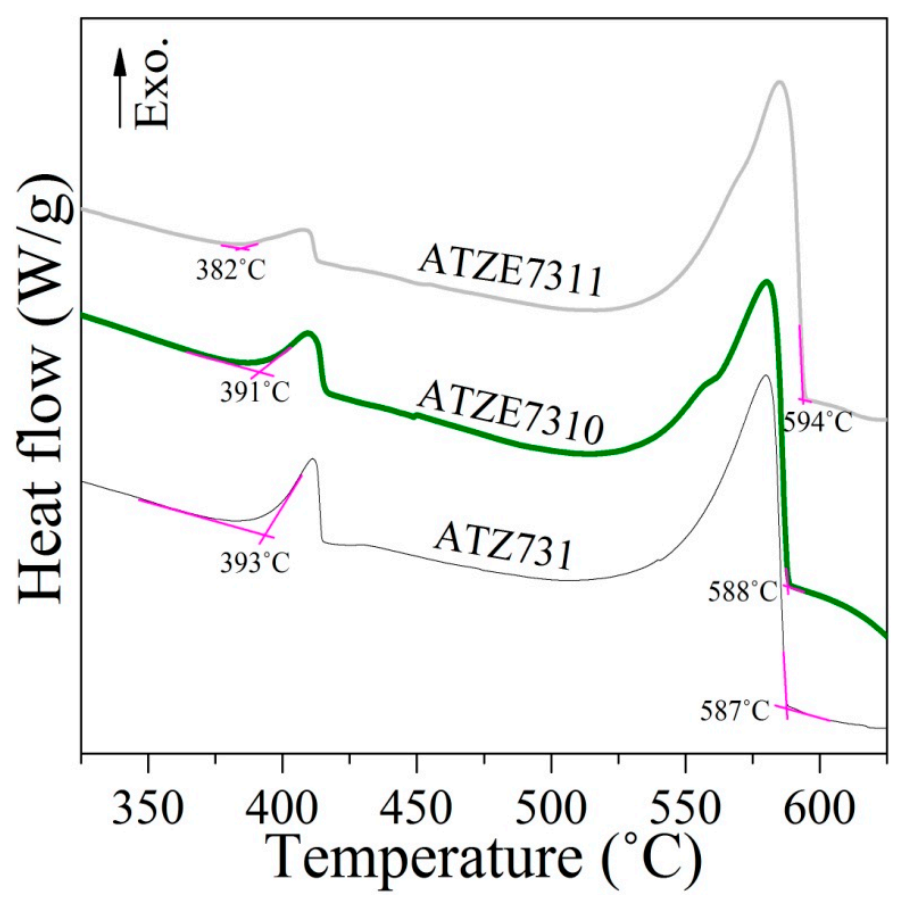

Figure 5. The typical DSC curves of as-cast samples for ATZ731, ATZE7310 and ATZE7311.

\subsection{Tensile Properties and Fracture Morphologies}

Figure 6 presents the engineering stress-strain curves of as-cast samples at RT and $175{ }^{\circ} \mathrm{C}$. The average values of UTS, YS, and $\mathrm{E}_{\mathrm{f}}$ are listed in Table 3 . It can be seen that small amounts of Mm remarkably improved the strength and elongation to failure of ATZ731 alloy at RT and $175^{\circ} \mathrm{C}$. With Mm increasing, the average UTS, YS and $E_{\mathrm{f}}$ of samples first increased and then slightly decreased in contrast with the based alloys. Among these specimens, ATZE7311 alloy exhibited the desirable combination of strength and ductility under tested conditions with the UTS, YS and $\mathrm{E}_{\mathrm{f}}$ of $\sim 239 \mathrm{MPa}, \sim 108 \mathrm{Mpa}$, and $\sim 19.6 \%$ at 
$\mathrm{RT}$, and they are $\sim 148 \mathrm{MPa}, \sim 102 \mathrm{Mpa}$, and $\sim 28 \%$ at $175^{\circ} \mathrm{C}$, improved by $\sim 9.6 \%, \sim 24.3 \%$, and $\sim 53.8 \%$, respectively, compared to ATZ731 alloy. It needs to be mentioned that the excessive Mm addition dropped the strength and ductility compared to ATZE7311 alloy, which was similar to the RE-containing Mg alloys, such as Y-adding AZ91 and Mm-adding ZK60 alloys [38,41,42].
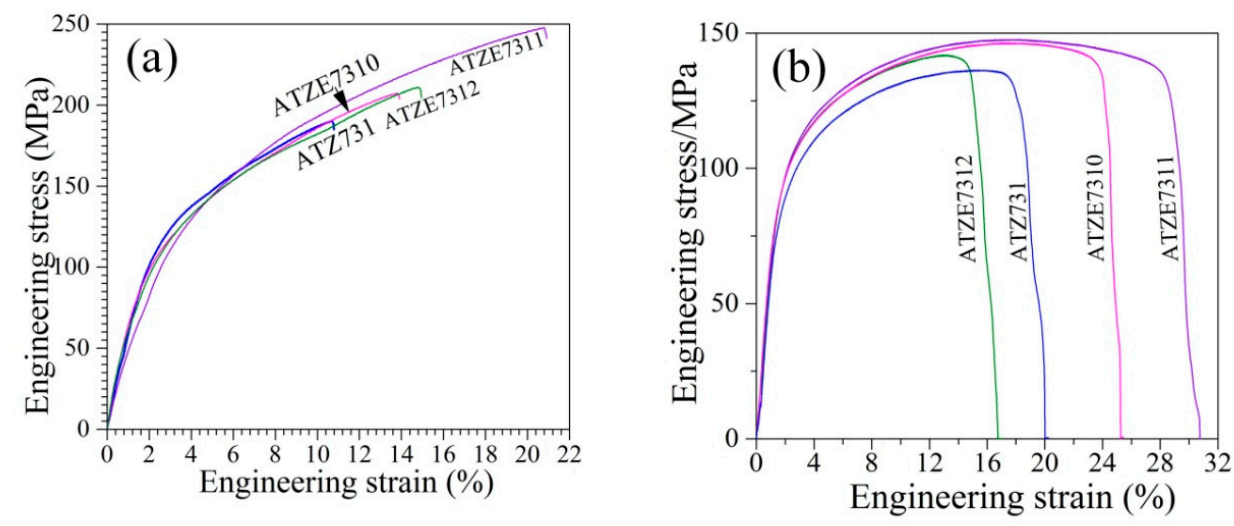

Figure 6. Engineering stress-strain curves of as-cast samples at (a) RT and (b) $175^{\circ} \mathrm{C}$.

Table 3. The average values of tensile properties of as-cast samples tested at RT and $175^{\circ} \mathrm{C}$.

\begin{tabular}{ccccccc}
\hline \multirow{2}{*}{ Alloy } & \multicolumn{3}{c}{ RT } & & $\mathbf{1 7 5}^{\circ} \mathbf{C}$ \\
\cline { 2 - 7 } & UTS (MPa) & YS (MPa) & $\mathbf{E}_{\mathbf{f}} \mathbf{( \% )}$ & UTS (MPa) & YS (MPa) & $\mathbf{E}_{\mathbf{f}}(\mathbf{\%})$ \\
\hline ATZ731 & $192 \pm 3$ & $95 \pm 3$ & $10.2 \pm 0.4$ & $129 \pm 2$ & $82 \pm 1$ & $18.2 \pm 1.1$ \\
ATZE7310 & $207 \pm 4$ & $91 \pm 1$ & $13.5 \pm 0.5$ & $145 \pm 2$ & $87 \pm 1$ & $23.6 \pm 1.1$ \\
ATZE7311 & $207 \pm 4$ & $108 \pm 2$ & $19.6 \pm 0.2$ & $148 \pm 3$ & $102 \pm 1$ & $28.0 \pm 0.3$ \\
ATZE7312 & $207 \pm 4$ & $94 \pm 3$ & $13.8 \pm 0.4$ & $139 \pm 6$ & $90 \pm 3$ & $17.2 \pm 0.5$ \\
\hline
\end{tabular}

Generally, the fracture models of $\mathrm{Mg}$ alloys are a mixture of cleavage and quasicleavage characters due to the limited plastic manners of $\{001\}<110>$ dislocation slip and $\{102\}<101>$ twin for Mg alloys at RT [43]. Figure 7 shows the typical fracture morphologies of specimens. The fractures of ATZ731 alloy showed few tear ridges and cleavage facets (Figure 7a), indicating that the major fractures model at RT is cleavage fracture. For ATZ731 alloys with Mm addition, few shallow dimples, tear ridges, and cleavage facets were observed on the fractures (Figure $7 \mathrm{~b}, \mathrm{c}, \mathrm{e}$ ), exhibiting the cleavage and quasi-cleavage characters, which usually occurred on Mg alloys. In the case of ATZE7312 alloys tested at $175^{\circ} \mathrm{C}$, the cleavage facets, tear ridges, and the relative deep dimples (Figure $7 \mathrm{~d}, \mathrm{f}$ ) showed that quasi-cleavage dominated the fracture model. Moreover, large amounts of fine particles are at the bottom of the dimples (Figure 7f), as expected to be beneficial to the tensile properties in contrast with that of ATZ731. Since the increasing deformation temperature of $175^{\circ} \mathrm{C}$ promoted the basal slip and activated the non-basal slip of $\mathrm{Mg}$ alloys, however, the ductility of ATZE7312 was slightly weak compared to ATZ731, possibly related to the non-uniform deformation caused by the progressive accumulation of $\mathrm{Al}_{4} \mathrm{Mm}$ phases during tensile tests [43]. 

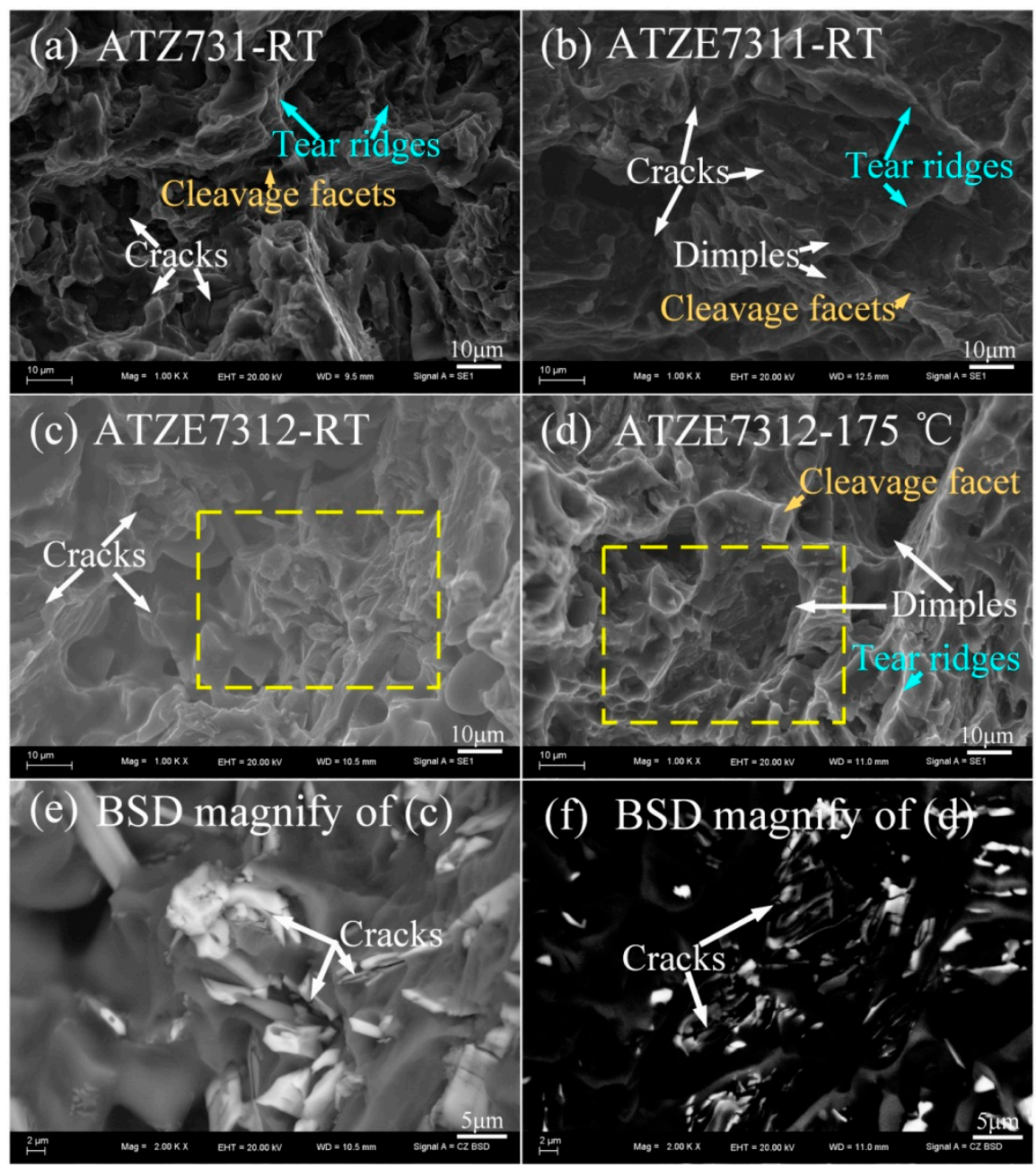

Figure 7. The typical tensile fracture morphologies of as-cast samples tested at RT and $175{ }^{\circ} \mathrm{C}$. (a) ATZ731 at RT; (b) ATZE7311-RT; (c) ATZE7312-RT; (d) ATZE7312-175 ${ }^{\circ}$ C; (e) and (f) are the high magnify BSD of local (c) and (d), respectively, as pointed by the dotted-line square.

The appropriate $\mathrm{Mm}$ addition enhanced the strength and ductility of as-cast ATZ731 alloys at RT and $175^{\circ} \mathrm{C}$ ascribed to the refined microstructures. The solid solution strengthening effects of ATZ731 alloy induced by Mm addition is limited because the solid solubility of $\mathrm{Mm}$ is very low in $\alpha-\mathrm{Mg}(\sim 0.74 \mathrm{wt} . \% \mathrm{Ce}$ in $\alpha-\mathrm{Mg})$ compared to those of the high solid solubility of $\mathrm{Al}, \mathrm{Zn}$, and $\mathrm{Sn}$ [29]. It is well known that the refined $\alpha$-Mg can greatly improve strength and ductility, especially for the YS. According to the formula of Hall-Petch, YS is proportional to a square root of grain size and Taylor's coefficient [44]. As a result, the refined $\alpha-\mathrm{Mg}$ ranging from $276 \mu \mathrm{m}$ of ATZ731 to $124 \mu \mathrm{m}$ of ATZE7311 progressively enhanced the YS regarding the large value of Taylor's coefficient of Mg.

For those as-cast Mg alloys, the morphology, size, and distribution of eutectic phases also greatly affected the strength and ductility by restricting the dislocation movement within grains and grain boundaries glide [44]. During the tensile deformation of samples, the dislocations were easily piled up near the grain boundaries, where plenty of hard and brittle eutectic phases existed at the interface between $\alpha-\mathrm{Mg}$ and eutectic phases. Once the density of dislocation is beyond a certain extent, it will cause the local stress concentration inducing the micro-cracks near these brittle phases and finally leading to the tensile failure (Figure 7). Due to this, for as-cast ATZ731 alloy during tensile deformation, cracks easily occur and develop along the grain boundaries in which mass of semi-continuous $\mathrm{Mg}_{17} \mathrm{Al}_{12}$ phases are distributed (Figures $2 \mathrm{a}$ and $7 \mathrm{a}$ ), resulting in low strength and poor ductility. As for ATZ731 alloy modified by Mm addition, there are two main factors that determine 
the tensile properties. One is the reduced grain size of $\alpha-\mathrm{Mg}$, which will enhance the tensile properties; the other is the eutectic phase, including volume fraction, morphology and distribution. The latter has a great effect on strength and ductility. As for ATZE7311 alloy, the homogeneously distributed refined eutectic phases (Figures 2c and 3) and the finest $\alpha-\mathrm{Mg}$ play enhanced roles in high strength and good ductility. With respect to ATZ731 alloy with $2.0 \mathrm{wt} . \% \mathrm{Mm}$ addition, the refined $\alpha-\mathrm{Mg}$ is beneficial to the strength and ductility (Figure $4 \mathrm{~d}$ ). On the contrary, the increased volume fraction of eutectic phases associated with more $\mathrm{Al}_{4} \mathrm{Mm}$ phase highly enriched at local regions (Figures $2 \mathrm{~h}$ and $7 \mathrm{f}$ ), such as grain boundaries, can improve the UTS but may lower the $Y S$ and $E_{f}$ [34]. Once the weakening effects induced by the locally enriched eutectic phases is far stronger than the enhancing roles afforded by the refined grains, a slight decrease of average $\mathrm{YS}$ at RT and $\mathrm{E}_{\mathrm{f}}$ at $175^{\circ} \mathrm{C}$ possibly occur. Additionally, it has been suggested that the concentration of defects in the solidified microstructures also decrease the strength and ductility in as-cast $\mathrm{Mg}$ alloys. Small amounts of $\mathrm{Mm}$ addition raised the transformation temperature of $\alpha-\mathrm{Mg}$, causing the relatively high cooling rates and reduction of defects in ATZ731 alloy during solidification. Fewer defects in the Mm-adding alloys were also helpful to improve their strength and ductility. Thus, the appropriate Mm addition could effectively improve strength and ductility owing to the solid solution strengthening, refinement strengthening, and the secondary phase strengthening [45-47].

\section{Conclusions}

The microstructures and tensile properties of Mg-7Al-3Sn-1Zn (ATZ731) alloys with 0-2.0 wt.\% Ce-rich misch metal (Mm) were studied. The results were as follows:

(1) The as-cast ATZ731 alloy consisted of $\alpha-\mathrm{Mg}, \mathrm{Mg}_{17} \mathrm{Al}_{12}$ and $\mathrm{Mg}_{2} \mathrm{Sn}$ phases. Minor addition of $\mathrm{Mm}$ promoted $\mathrm{Al}_{4} \mathrm{Mm}$ but restricted $\mathrm{Mg}_{17} \mathrm{Al}_{12}$ phase.

(2) Minor addition of Mm refined grain size and eutectic phases of ATZ731. With the increasing addition of $\mathrm{Mm}$, the $\mathrm{Mg}_{17} \mathrm{Al}_{12}$ phase became from semi-continuous to blockand particle-like along the grain boundaries, while $\mathrm{Al}_{4} \mathrm{Mm}$ phases changed from rod-like to feather-like distributed at grain boundaries and within grains.

(3) The appropriate Mm addition enhanced the strength and ductility of ATZ731 alloy at RT and $175^{\circ} \mathrm{C}$. ATZ731 alloy with $1.0 \mathrm{wt} . \% \mathrm{Mm}$ addition exhibited the high strength and good ductility with the UTS, YS and $\mathrm{E}_{\mathrm{f}}$ are $\sim 239 \mathrm{MPa}, \sim 108 \mathrm{MPa}$ and $\sim 19.6 \%$ at RT and $\sim 148 \mathrm{MPa}, \sim 102 \mathrm{MPa}$ and $\sim 28 \%$ at $175^{\circ} \mathrm{C}$, respectively. Compared to ATZ731, they are improved by $\sim 14.7 \%, \sim 24.3 \%$ and $\sim 53.8 \%$ at $175{ }^{\circ} \mathrm{C}$, mainly owing to the refined microstructures. The fractures of alloys exhibited the mixture characters of cleavage and quasi-cleavage, indicating that $\mathrm{Mm}$ addition did not change the fracture mode.

Author Contributions: Conceptualisation, G.-J.L. and Y.-H.S.; methodology, G.-J.L., N.X. and X.-F.G.; validation, G.-J.L., Y.-H.S., N.X. and X.-F.G.; investigation, G.-J.L., N.X. and X.-F.G.; writing—original draft preparation, G.-J.L.; writing-review and editing, G.-J.L., and N.X.; project administration, G.-J.L.; funding acquisition, G.-J.L. All authors have read and agreed to the published version of the manuscript.

Funding: This research was funded by the National Natural Science Foundation of China (No. 51301074) and the Research Foundation of Education Bureau of Jilin Province, China (No.JJKH20211082KJ).

Institutional Review Board Statement: Not applicable.

Informed Consent Statement: Not applicable.

Data Availability Statement: Not applicable.

Conflicts of Interest: The authors declare no conflict of interest.

\section{References}

1. Liu, B.Y.; Liu, F.; Yang, N.; Zhai, X.B.; Zhang, L.; Yang, Y.; Li, B.; Li, J.; Ma, E.; Nie, J.F.; et al. Large plasticity in magnesium mediated by pyramidal dislocations. Science 2019, 365, 73-75. [CrossRef]

2. Ogawa, Y.; Ando, D.; Sutou, Y.; Koike, J. A lightweight shape-memory magnesium alloy. Science 2016, 353, 368-370. [CrossRef] 
3. Song, J.; She, J.; Chen, D.; Pan, F. Latest research advances on magnesium and magnesium alloys worldwide. J. Magnes. Alloy. 2020, 8, 1-41. [CrossRef]

4. Xu, T.; Yang, Y.; Peng, X.; Song, J.; Pan, F. Overview of advancement and development trend on magnesium alloy. J. Magnes. Alloy. 2019, 7, 536-544. [CrossRef]

5. Jo, S.M.; Kim, S.D.; Kim, T.H.; Go, Y.; Yang, C.W.; You, B.S.; Kim, Y.M. Sequential precipitation behavior of $\mathrm{Mg}_{17} \mathrm{Al}_{12}$ and $\mathrm{Mg}_{2} \mathrm{Sn}$ in Mg-8Al-2Sn-1Zn alloys. J. Alloy. Compd. 2018, 749, 794-802. [CrossRef]

6. Kim, S.; Un, J.; Jin, Y.; Jung, J.; Hyuk, S. Controlling the microstructure and improving the tensile properties of extruded Mg-Sn-Zn alloy through Al addition. J. Alloy. Compd. 2018, 751, 1-11. [CrossRef]

7. Kim, J.K.; Oh, S.H.; Kim, K.C.; Kim, W.T.; Kim, D.H. Effect of Sn addition on the precipitation behavior in AZ91 magnesium alloy. Mater. Trans. 2017, 58, 963-966. [CrossRef]

8. Kabir, A.S.; Sanjari, M.; Su, J.; Jung, I.H.; Yue, S. Influence of static precipitation on microstructure and texture of annealed cold-rolled Mg-Al-Sn alloys. Metall. Mater. Trans. B 2015, 46, 1674-1683. [CrossRef]

9. Guan, M.; Hu, Y.; Zheng, T.; Zhao, T.; Pan, F. Composition optimization and mechanical properties of Mg-Al-Sn-Mn alloys anode for Mg-air batteries. Mater. Des. 2018, 137, 1424. [CrossRef]

10. Davis, A.E.; Robson, J.D.; Turski, M. The effect of multiple precipitate types and texture on yield asymmetry in Mg-Sn-Zn (-Al-Na-Ca) alloys. Acta Mater. 2018, 158, 1-12. [CrossRef]

11. Wang, C.; Zhang, H.Y.; Wang, H.Y.; Liu, G.J.; Jiang, Q. Effects of doping atoms on the generalized stacking-fault energies of Mg alloys from first-principles calculations. Scr. Mater. 2013, 69, 445-448. [CrossRef]

12. Liu, H.; Chen, Y.; Zhao, H.; Wei, S.; Gao, W. Effects of strontium on microstructure and mechanical properties of as-cast Mg-5wt.\% Sn alloy. J. Alloy. Compd. 2010, 504, 345-350. [CrossRef]

13. Majd, A.M.; Farzinfar, M.; Pashakhanlou, M.; Nayyeri, M.J. Effect of RE elements on the microstructural and mechanical properties of as-cast and age hardening processed Mg-4Al-2Sn alloy. J. Magnes. Alloy. 2018, 6, 309-317. [CrossRef]

14. Kabir, A.S.; Sanjari, M.; Su, J.; Jung, I.H.; Yue, S. Effect of strain-induced precipitation on dynamic recrystallization in Mg-Al-Sn alloys. Mater. Sci. Eng. A 2014, 616, 252-259. [CrossRef]

15. Xiong, H.; Yu, K.; Yin, X.; Dai, Y.; Yan, Y.; Zhu, H. Effects of microstructure on the electrochemical discharge behavior of Mg-6wt $\%$ Al-1wt\% Sn alloy as anode for Mg-air primary battery. J. Alloy. Compd. 2017, 708, 652-661. [CrossRef]

16. Klarner, A.D.; Miao, J.; Sun, W.; Luo, A.A.; Zeng, X. The Effects of Silicon Addition on the Microstructure and Mechanical Properties of a Mg-Al-Sn Alloy Produced by Vacuum Assisted High Pressure Die Casting. Metall. Mater. Trans. A 2019, 50, 1522-1533. [CrossRef]

17. Luo, A.A.; Fu, P.; Peng, L.; Kang, X.; Li, Z.; Zhu, T. Solidification microstructure and mechanical properties of cast magnesiumaluminum-tin alloys. Metall. Mater. Trans. A 2012, 43, 360-368. [CrossRef]

18. Wang, H.Y.; Rong, J.; Liu, G.J.; Zha, M.; Wang, C.; Luo, D.; Jiang, Q.C. Effects of Zn on the microstructure and tensile properties of as-extruded Mg-8Al-2Sn alloy. Mater. Sci. Eng. A 2017, 698, 249-255. [CrossRef]

19. Wu, H.Y. Effects of Zn Addition on Microstructure and Mechanical Properties of Mg-8Al-2Sn Alloy. Rare Metal Mat. Eng. 2019, 7 , 2091-2098. (In Chinese)

20. Liu, C.; Chen, H.; He, C.; Zhang, Y.; Nie, J.F. Effects of Zn additions on the microstructure and hardness of Mg-9Al-6Sn alloy. Mater. Charact. 2016, 113, 214-221. [CrossRef]

21. Sasaki, T.T.; Oh-Ishi, K.; Ohkubo, T.; Hono, K. Enhanced age hardening response by the addition of Zn in Mg-Sn alloys. Scr. Mater. 2006, 55, 251-254. [CrossRef]

22. Sasaki, T.T.; Oh-Ishi, K.; Ohkubo, T.; Hono, K. Effect of double aging and microalloying on the age hardening behavior of a Mg-Sn-Zn alloy. Mater. Sci. Eng. A 2011, 530,1-8. [CrossRef]

23. Wang, J.; Fu, J.; Dong, X.; Yang, Y. Microstructure and mechanical properties of as-cast Mg-Al-Sn-Y-Nd alloy. J. Mater. 2012, 36, 432-437. [CrossRef]

24. Xiao, W.; Jia, S.; Wang, J.; Yang, J.; Wang, L. The influence of mischmetal and tin on the microstructure and mechanical properties of Mg-6Zn-5Al-based alloys. Acta. Mater. 2008, 56, 934-941. [CrossRef]

25. Zhang, J.; Leng, Z.; Liu, S.; Zhang, M.; Meng, J.; Wu, R. Structure stability and mechanical properties of Mg-Al-based alloy modified with Y-rich and Ce-rich misch metals. J. Alloy. Compd. 2011, 509, L187-L193. [CrossRef]

26. Zhang, J.; Yu, P.; Liu, K.; Fang, D.; Tang, D.; Meng, J. Effect of substituting cerium-rich mischmetal with lanthanum on microstructure and mechanical properties of die-cast Mg-Al-RE alloy. Mater. Des. 2009, 30, 2372-2378. [CrossRef]

27. Jia, R.; Yu, S.; Li, D.; Zhang, T.; Wang, F.; Zhong, C. Study on the effect of mischmetal (La, Ce) on the micro-galvanic corrosion of AZ91 alloy using multiscale methods. Journal of Alloys and Compounds. J. Alloy. Compd. 2019, 778, 427-438. [CrossRef]

28. Liu, W.; Cao, F.; Chang, L.; Zhang, Z.; Zhang, J. Effect of rare earth element Ce and La on corrosion behavior of AM60 magnesium alloy. Corros. Sci. 2009, 51, 1334-1343. [CrossRef]

29. Xu, Y.; Zhang, K.; Lei, J. Effect of mischmetal on mechanical properties and microstructure of die-cast magnesium alloy AZ91D. J. Rare Earths 2016, 34, 742-746. [CrossRef]

30. Kang, S.B.; Kim, H.W.; Jeong, S.S.; Kim, J.W. Influence of misch metal addition and deformation processes on microstructure and mechanical properties in AZ61 alloy. Mater. Sci. Forum 2007, 543, 1707-1712. [CrossRef]

31. Liao, H.M.; Long, S.Y.; Guo, C.B.; Zhu, Z.B. Effect of Ce-rich misch metal addition on squeeze cast microstructure and mechanical properties of AZ81 alloy. Trans. Nonferrous Met. Soc. 2008, s1, 1-6. [CrossRef] 
32. Tang, B.; Ai, Z.D.; Ai, G.X. Grain coarsening behavior of Mg-A1 alloys with mischmetal addition. J. Rare Earths 2007, 25, 227-232.

33. Luo, D.; Wang, H.Y.; Zhao, L.G.; Wang, C.; Liu, G.J.; Liu, Y.; Jiang, Q.C. Materials Characterization Effect of differential speed rolling on the room and elevated temperature tensile properties of rolled AZ31 Mg alloy sheets. Mater. Charact. 2017, 124, 223-228. [CrossRef]

34. Su, J.; Guo, F.; Cai, H.; Liu, L. Structural analysis of Al-Ce compound phase in AZ-Ce cast magnesium alloy. J. Mater. Res. Technol. 2019, 6, 6301-6307. [CrossRef]

35. Wu, X.; Chen, M.; Qu, R.; Li, Q.; Guan, S. Effect of simultaneous addition of Mn and mischmetal on the high temperature deformation behavior of AZ61 magnesium alloy. Mater. Trans. 2017, 58, 1000-1006. [CrossRef]

36. Pettersen, G.; Westengen, H.; Høier, R.; Lohne, O. Microstructure of a pressure die cast magnesium-4wt.\% aluminium alloy modified with rare earth additions. Mater. Sci. Eng. A 1996, 207, 115-120. [CrossRef]

37. Guo, F.; Li, P.; Gao, X.; Xu, J. Study on solid solution and aging process of AZ91D magnesium alloy with cerium. J. Rare Earths. 2010, 28, 948-951. [CrossRef]

38. Kim, S.; Hyuk, S. Influence of Ce addition and homogenization temperature on microstructural evolution and mechanical properties of extruded Mg-Sn-Al-Zn alloy. Mater. Sci. Eng. A 2016, 676, 232-240. [CrossRef]

39. Li, J.F.; Geng, H.R.; Wang, Y.Z.; Cui, F.; Sun, C.J. Effects of Y on microstructure and mechanical properties of AZ91 magnesium alloy. Foundry 2005, 54, 53-56. (In Chinese)

40. Shen, N.; Tang, Y.; Guan, S.; Zhang, D. Solidification theory and rapid solidification. Acta Metall. Sin. 1996, 7, 673-684.

41. Birbilis, N.; Easton, M.A.; Sudholz, A.D.; Zhu, S.M.; Gibson, M.A. On the corrosion of binary magnesium-rare earth alloys. Corros. Sci. 2019, 51, 683-689. [CrossRef]

42. Silva, E.P.; Marques, F.; Nossa, T.S.; Alfaro, U.; Pinto, H.C. Impact of Ce-base mischmetal on the microstructure and mechanical behavior of ZK60 magnesium casting alloys. Mater. Sci. Eng. A 2018, 723, 306-313. [CrossRef]

43. Hall, E.O. The deformation and ageing of mild steel: II Characteristics of the Lüders deformation. Proc. Phys. Soc. Sect. B 1951, 64, 742-747. [CrossRef]

44. Kim, W.J.; Jeong, H.G.; Jeong, H.T. Achieving high strength and high ductility in magnesium alloys using severe plastic deformation combined with low-temperature aging. Scr. Mater. 2009, 61, 1040-1043. [CrossRef]

45. Wang, L.; Li, Y.; Zhang, H.; Zhang, Z.; Yang, Q.; Zhang, Q.; Wang, H.; Cheng, W.; Shin, K.S.; Vedani, M. Review: Achieving enhanced plasticity of magnesium alloys below recrystallization temperature through various texture control methods. J. Mater. Res. Technol. 2020, 9, 12604-12625. [CrossRef]

46. Song, B.; Yang, Q.; Zhou, T.; Chai, L.; Guo, N.; Liu, T.; Guo, S.; Xin, R. Texture control by $\{10-12\}$ twinning to improve the formability of Mg alloys: A review. J. Mater. Sci. Technol. 2019, 35, 2269-2282. [CrossRef]

47. Wang, H.; Zhang, H.; Xu, X.; Zha, M.; Wang, C.; Ma, P.; Guan, Z. Current Research and Future Prospect on Microstructure Stability of Superplastic Light Alloys. Acta Metall. Sin. 2018, 11, 1618-1624. [CrossRef] 